cords its passage by a unanimous vote of that body. The fact is, everybody. favored and nobody opposed this meritorious bill (House File No. 60).

\title{
SLAVERY LEGISLATION IN IOWA.
}

There was presented in the last number of The Annals. (pp. 145-147) "an act to regulate Blacks and Mulattoes," which was passed by our first Territorial legislature and approved by Gov. Lucas. We can find no law by which it was ever directly repealed, but it would seem practically to have been a dead letter from the first. In the changed sentiment of these times such a law would be universally regarded as nothing less than infamous. It is a veritable curiosity, and might well be included by Dr. Shambaugh among his "materials for history." Men are now living to whom such laws were familiar-for they existed in many Northern States; yet, to the thoughts and feelings of the generation which now rules this country, the impulses which inspired them are as far removed and as much out of dateas foreign to the thoughts of the people-as the events which led to the war for American Independence. The great statesmen who became famous-whose names were "familiar as household words"-from their warfare upon slavery, are but seldom mentioned in these days. Their names are well-uigh forgotten by the mass of their countrymen, and their patriotic and humane lahors, which were deemed herculean in their day, only possess interest to the students of history. Mould is fast gathering upon their memories. Even the god-like Charles Sumner is seldom referred to, and the great edition of his speeches and writings, which he supervised with such scholarly care, receives little attention in the public libraries.

\section{A VALUABLE DONATION.}

Hon. Theodore S. Parvin quite recently sent to the Historical Department thirty bound volumes of early Iowa newspapers which thus become the property of the State. 
Copyright of Annals of Iowa is the property of State of Iowa, by \& through the State Historical Society of Iowa and its content may not be copied or emailed to multiple sites or posted to a listserv without the copyright holder's express written permission. However, users may print, download, or email articles for individual use. 